\title{
Examination of the effects of STEM education integrated as a part of science, technology, society and environment courses
}

\author{
Bekir Yildırım ${ }^{1}$ \\ Mahmut Selvi $^{2}$
}

\begin{abstract}
This study was carried out to determine the view of prospective teachers with regard to STEM education given in Science, Technology, Society and Environment course and the effects of STEM education on prospective teachers' attitudes towards renewable energy sources and awareness of environment problems. The study was carried out in 2014-2015 academic year with 76 prospective science teachers. In the study, mixed method research design, which employs qualitative and quantitative research methods together, has been used. As a data collection tool "Sensitivity to Environment Problems Scale", "Attitude Scale for Renewable Energy Resources" and "Semistructured Interview Form" developed by the researcher were used. Data obtained as a result of content analysis were coded. As a result of analysis of the study, it was determined that prospective teachers' attitudes towards renewable energy resources were positively affected but there was no change in their level of awareness of environmental problems.
\end{abstract}

Keywords: STEM; Renewable Energy; Science; Society; Technology

\section{Introduction}

In recent years, changes in science, technology and economy radically transformed countries points of views towards education. In this point of view, it has been revealed that teaching science, technology, and engineering and mathematics disciplines separately is not sufficient and that these disciplines are to be taught together with the skills needed in the 21 st century. This integration of instruction has changed expectations from individuals, as well. As a result of these expectations, a new trend called STEM education has emerged.

STEM was first introduced by Dr. Judith Rahmaley in 2001 (Ylldırım \& Altun, 2015, s.29; Koonce et al. 2011; Dugger, 2010). Although STEM education is a new concept, its significance was newly appreciated by educators (White, 2104). STEM education is defined differently by various groups and organizations. According to Gonzalez and Kuenzi (2012), the acronym STEM refers to the academic discipline of Science, Technology, Engineering and Mathematics. Even if STEM is the abbreviations of these disciplines, it contains a larger and more comprehensive meaning (Yildırım \& Selvi, 2015).

\subsection{The significance of the study}

\footnotetext{
1 Assist. Prof. Dr., Muş Alparslan University, Faculty of Education, Department of Mathematics and Science Education, bekir58bekir@gmail.com

2 Prof. Dr., Gazi University, Faculty of Education, Department of Mathematics and Science Education, selvimahmut@gmail.com
} 
Yıldırım, B., \& Selvi, M. (2016). Examination of the effects of STEM education integrated as a part of science, technology, society and environment courses. Journal of Human Sciences, 13(3), 3684-3695. doi: $10.14687 /$ ihs.v13i3.3876

Training qualified prospective teachers now will be one of the most important determinants for the reconstruction of students and society they will teach. Education aims to equip prospective teachers' skills that will help them solve the problems they face. Education aims to help prospective teachers to develop themselves scientifically and academically and train their students as physically, mentally, spiritually and emotionally balanced and healthy individuals. Education aims to train prospective teachers as individuals who think scientifically, criticize and are creative and productive individuals who accept others as they are, respect human rights, value people as human beings, responsible for the country and the society they grow in. Considered in this context, well-educated prospective teachers play a great role for the development of the country in every aspect. Therefore, prospective science teachers are to be adequately equipped with information and skills in science, technology, engineering and mathematics education and to apply these disciplines in their life.

\subsection{The aim of the study}

The aim of this study is to determine the views of prospective science teachers about STEM education, and the effects of STEM education on the attitudes of prospective teachers' attitudes toward renewable energy resources and their awareness of environment problems. Based on this general aim, answer for the following questions have been sought.

1. Is there a significant difference between the pre-test and post-test scores of the group of students who received STEM education on the scale measuring their attitudes towards Renewable energy resources?

2. Is there a significant difference between pre-test and post-test scores of the group of the students who received STEM education on awareness of environmental problems?

3. What are the views of prospective science teachers STEM on education?

\section{Method}

As this study aims to reveal the results of STEM education integrated into STSE course in all dimensions and to strengthen the results, mixed research method has been employed in this study. The basic aim of employing mixed research methods in studies is to strengthen quantitative and qualitative research methods. In line with this design, pre-test and post-test quasi-experimental design with one group has been used. Interview method was used to collect qualitative data.

\subsection{The study group}

In the study, opportunity sampling technique have been used. The study group is composed of 76 fourth grade students attending Science Education department at the Faculty of Education, Muss Alparslan University. The study was implemented during 2014-2015 fall period.

\subsection{Data collection}

\subsubsection{Renewable energy resources attitude scale}

In the study, "Renewable Energy Resources Attitude Scale" developed by Güneş, Alat and Can Gözüm (2013) as a Likert Scale, was used. This scale was administrated to 402 students attending science education department. The Renewable Energy Resources Attitude Scale developed by Güneş et al. was submitted to factor analysis to achieve construct validity and four factors: "the desire to apply", "importance of education", "country's interests", "environmental consciousness 
Yildırım, B., \& Selvi, M. (2016). Examination of the effects of STEM education integrated as a part of science, technology, society and environment courses. Journal of Human Sciences, 13(3), 3684-3695. doi: $10.14687 /$ ihs.v13i3.3876

and investments" have been constructed considering the Eigen values. The researcher found that the Cronbach Alpha value of the whole scale is .87 . The highest score to be obtained on the scale is 110 ; the lowest score is 22 . The final version of the scale is composed of 26 items. The reliability of the Renewable Energy Resources Attitude Scale (RERAS) has been tested again. RERAS has been administrated to a total of 185 1st, 2nd, 3rd and 4th grade students attending science education department and Cronbach alpha reliability value was found to be 0.82 . Accordingly, the scale was used in the study.

\subsubsection{Environmental problems awareness scale}

In line with the aim of the study, Environmental Problems Awareness Scale developed by Güven and Aydoğdu (2012) was used. Developed as a three-point Likert scale, the scale has a total of 44 items. The scale has 6 factors and the Cronbach alpha value was determined to be found 0.90 . These results indicate that the scale is valid and reliable. The researcher tested the reliability of the environmental problems awareness scale (EPAS) once more. The EPAS was administrated to 145 3rd and 4th grade students attending science education department and Cronbach alpha reliability value was found to be 0.85 .

\subsubsection{Semi-structured interview form}

After theoretical framework of the study had been developed, semi-structured interview form was developed to get the views of prospective science teachers about STEM education. After the form had been developed, initial interviews were made with three prospective science teachers and the questions in the interview form was revised based on the opinions of prospective teachers after the interviews. Finally, the responds given to the interview questions were analyzed using content analysis.

\subsection{Data analysis}

Qualitative data obtained were analyzed using the content analysis technique. Codes were developed as a result of content analysis. Expert view and support were received for data analysis. Quantitative data obtained were analyzed with SPSS package program.

\section{Results}

In this section of the study, the findings obtained as a result of the analysis of data collected in line with the aims of the study were interpreted in the framework of the research questions. To answer the question "Is there a significant difference between pre-test and post-test attitude to renewable energy resources scores of the students in the group where STEM education was given?", pre-test and post-test mean scores and standard deviations were calculated and t-test was used to find out the significance of the difference.

Table 1. Pre-test Post-test Scores of the Group Related to their Attitudes to Renewable Energy Resources

\begin{tabular}{lccccc}
\hline & $\mathbf{N}$ & $\overline{\mathbf{X}}$ & $\mathbf{S}$ & $\mathbf{s d}$ & $\mathbf{t}$ \\
\hline Pre-test & 76 & 103.37 & 14.408 & 67 & $3,198^{*}$ \\
Post test & 76 & 110.40 & 10.751 & & \\
\hline
\end{tabular}

${ }^{*} \mathrm{p}<0.05$ is the significance level. 
Yllırım, B., \& Selvi, M. (2016). Examination of the effects of STEM education integrated as a part of science, technology, society and environment courses. Journal of Human Sciences, 13(3), 3684-3695. doi: $10.14687 /$ ihs.v13i3.3876

When Table 1 is examined, it is seen that there is a significant difference between the pre-test $(\overline{\mathrm{x}}=$ 103.37) mean score and post-test mean score $(\bar{x}=110.40)$ of the group $\left(t_{(67)}=3.198 ; \mathrm{p}<, 05\right)$.

2. To find the answer for the question "Is there a significant difference between the pre-test and post-test attitudes to environmental problems scale mean scores of the students where STEM education was given?", the pre-test and post-test mean scores and standard deviations of the group was plural calculated and t-test was used to find out the significance of the difference between the pre-test and post-test mean scores.

Table 2. The Pre-test and Post-test Results of the Group on Environmental Problems Awareness Scale

\begin{tabular}{lccccc}
\hline & $\mathbf{N}$ & $\overline{\mathbf{X}}$ & $\mathbf{S}$ & $\mathbf{s d}$ & $\mathbf{t}$ \\
\hline Pre test & 76 & 62,92 & 8,233 & 75 & $1.038^{*}$ \\
Post test & 76 & 64,05 & 5,638 & & \\
\hline
\end{tabular}

$*$ the result is not significant according to $\mathrm{p}<0.05$.

When Table 2 is examined, it is seen that there is not a significant difference between the pre-test mean score $(\bar{x}=62,92)$ and the post-test mean score $(\bar{x}=64,05)$ of the group $\left(t_{(75)}=1,038 ; p>, 05\right)$.

3. As for the question of "What are the views of prospective science teachers with regard to STEM education?, the students' views were taken. The main themes in line with these views are given in the table below.

Table 3. Frequency and percentage distribution of prospective teachers' views about STEM education

\begin{tabular}{lcc}
\hline Main Themes & $\mathbf{F}$ & $\mathbf{\%}$ \\
\hline It is an interdisciplinary approach & 25 & 32,89 \\
\hline Ensures active participation & 25 & 32,89 \\
\hline Allows group work & 24 & 31,58 \\
\hline Develops problem solving skills & 22 & 28,94 \\
\hline Against rote-learning & 20 & 26,31 \\
\hline Encourage imagination & 17 & 22,37 \\
\hline Ensures meaningful and permanent learning & 16 & 21,05 \\
\hline Complies with the constructivist approach & 17 & 22,37 \\
\hline Ensures learning by doing & 16 & 21,05 \\
\hline Contributes to the development of science and technology & 15 & 19,73 \\
\hline Develops critical thinking skills & 15 & 19,73 \\
\hline Contributes to national economy & 14 & 18,42 \\
\hline Facilitate the understanding in the course through models & 14 & 18,42 \\
\hline Involves real life learning problems and related to daily life & 11 & 14,47 \\
\hline Develops the curiosity & 11 & 14,47 \\
\hline Entertaining & 10 & 13,16 \\
\hline Ensures bringing up qualified individuals & 7 & 9,21 \\
\hline Develops individuals' creativity & 7 & 9,21 \\
\hline Develops psychomotor skills & 5 & 6,58 \\
\hline
\end{tabular}

When the table is examined, it is seen that prospective science teachers have a great many positive opinions about STEM education. 32,89\% $(n=25)$ of the prospective teachers marked that STEM education is an interdisciplinary approach and ensure active participation of the students. $31,58 \%$ 
Yıldırım, B., \& Selvi, M. (2016). Examination of the effects of STEM education integrated as a part of science, technology, society and environment courses. Journal of Human Sciences, 13(3), 3684-3695. doi: $10.14687 /$ ihs.v13i3.3876

$(\mathrm{n}=24)$ of the prospective teachers stated that STEM education allowed group work, 28,94\% $(n=22)$ stated that it contributed to problem solving skills, 26,31\% $(n=20)$ stated that it is against rote-learning. Besides, STEM education has many positive aspects (see Table 3). In addition, according to the prospective teachers, STEM education helps development of the $21^{\text {st }}$ century skills (critical thinking, creativity and problem solving skills). Furthermore, the prospective teachers stated that STEM education will contribute to the economic, technological and scientific development of the country. Samples of excerpts from the interviews with the prospective teachers with regard to the themes presented in the table are as follows:

X6:...It will allow us to get rid of the (learning) process in which the teacher tells and the students listen and listen and impatiently waits by thinking "when will the bell ring?" and to creates more fruitful process.

$\mathrm{X} 10: \ldots$ There is a need for qualified man power to use knowledge that influences countries' economy. To reach this man power, systematic and applicable studies are to be made on STEM education which has become the focal point of modern day and which will enable education systems to train qualified, productive and creative individuals.

X12: Thanks to STEM education, students will use their relation establishment, modelling and problem solving skills which are based on interdisciplinary cooperation rather than learning with classical rote-learning based methods in which scientific concepts and information are not related to daily life.

X15: ... the aim of STEM, which means science, technology, engineering and mathematics; is a project in which these subjects are taught based on the constructivist approach by attaching greater importance to practice and increase students' creativity power rather than asking them to memorize well-known formulas.

X16:...STEM education is an education model which rejects rote-learning and which does not suffice with theory but which is developed with practices.

$\mathrm{X} 17: \ldots$ STEM is a project which does not regard mathematics or science as a subject but allows learners to apply the knowledge they acquire to life.

X20:...STEM education is the integrated use of Mathematics, Engineering, Science and Technology in education.

$\mathrm{X} 21: \ldots$. STEM education is a system which aims to free the subject taught from theory and tries to make it more practical.

X22:...STEM education is not leaving what we have learnt so far in theory. In other words, it is training critical and creative individuals who do not say "yes" to whatever told them but who reason, probe.

Even though prospective science teachers have positive views about STEM education, they also have some negative opinions of it. Relevant information about it is given in the table below (see Table 4.). 
Yildırım, B., \& Selvi, M. (2016). Examination of the effects of STEM education integrated as a part of science, technology, society and environment courses. Journal of Human Sciences, 13(3), 3684-3695. doi: $10.14687 /$ ihs.v13i3.3876

Table 4. Frequency and percentage distribution of Negative opinions of prospective teachers about STEM education

\begin{tabular}{lcc}
\hline Main Themes & $\mathbf{F}$ & $\mathbf{0}$ \\
\hline Takes more time and difficulty & 19 & 25 \\
\hline Some group members are inactive and thus isolated & 14 & 18,42 \\
\hline Costly & 4 & 5,26 \\
\hline Difficulty to implement in crowded classes & 2 & 2,63 \\
\hline Working environment is not suitable for research & 2 & 2,63 \\
\hline
\end{tabular}

$*$ Percentages are calculated based on 76 people.

When Table 4 is examined, $25 \%$ of the prospective teachers in the study group stated that the implementation takes time and it is difficult. 18,42\% stated that "some group members are inactive and thus isolated", 5,26\% stated that it was "Costly" and 2,63\% stated that it was "Difficult to implement in crowded classes" and "working atmosphere is not suitable for research". Samples of excerpts from the prospective teachers' interviews related to the information presented in the table are as follows:

X26:...STEM education encourages students to think but it takes a lot of time and it is very difficult. Perhaps it is because we are not used to thinking that much.

X32:...Individuals who are shy in cooperative working environments can pale beside or it can lead to discussions among members.

As a result of STEM education implementation Science, Technology, Society and Environment, some prospective science teachers have developed misconceptions about STEM education. The misconceptions are given in the table below (see Table 5).

Table 5. Misconceptions prospective Science teachers developed related to STEM education

\begin{tabular}{lcc}
\hline Main Themes & F & $\mathbf{\%}$ \\
\hline STEM education is given using Legos & 9 & 11,84 \\
\hline STEM education is suitable only for physics classes & 2 & 2,63 \\
\hline STEM education is given using toys & 2 & 2,63 \\
\hline STEM education is given only to gifted children & 1 & 1,32 \\
\hline
\end{tabular}

When Table 5 is examined, $11,84 \%(n=9)$ of the prospective science teachers think that STEM education is given via Legos, 2,63\% $(\mathrm{n}=2)$ think that is is only applied in physics classes. Besides, $2,63 \% \quad(n=2)$ of the prospective teachers think that STEM education is given with toys and 1,32\% $(n=1)$ think that it is given to only gifted children. Samples of excerpts from the prospective teachers' interviews related to the information presented in the table are as follows:

X3: ...STEM education is a process which involves playing with toys and learning.

X4: ...STEM should not be only for gifted children but for all children...

X6: ...STEM education can be started at pre-schools. Because children at this age like playing with toys. 
Yildirım, B., \& Selvi, M. (2016). Examination of the effects of STEM education integrated as a part of science, technology, society and environment courses. Journal of Human Sciences, 13(3), 3684-3695. doi: $10.14687 /$ ihs.v13i3.3876

X8:...using these Legos in STEM education will be very beneficial both for students' learning and the country's development in scientific areas like engineering.

$\mathrm{X} 14: \ldots$ STEM is an educational system used to make learners love the school, and make it more entertaining by using robots or other pieces.

X18:...As far as we learn, we know that the topics are taught especially using toys.

X25:...I think STEM is developing your own creativity using Legos.

X30:...I can say that STEM provides materials for the teaching of terms that can only be applied with Legos.

Prospective science teachers were asked "What is STEM education?". The responds prospective teachers provided for this question are given below:

X1: ...STEM is actually a system which uses and supports creativity that we have at young ages and focuses on finding solutions based on the feeling of curiosity.

X2: ...In fact, STEM is a system that uses, supports and triggers creativity we have at younger ages and which focuses on problem based working and on finding solutions based on the feeling of curiosity children have.

X4: STEM is an education system used to create and sustain a skillful society.

$\mathrm{X} 7$ : STEM education is a system which aims to develop students in every field.

X10: STEM education stands for Science, Technology, Engineering and Mathematics; it is the task of giving education using these four disciplines.

X13:...STEM education involves teaching and learning science, technology, engineering and mathematics.

X15: ...STEM is used in science, technology, engineering and mathematics. Its aim is to increase creativity of students by attaching greater importance to practicality based on the constructivist approach rather than teaching theory by making learners memorize familiar formulas.

X23:...STEM education is a system which aims to unfold natural creativity skills of human beings.

X25:...I have always hated giving solely theoretical information and making learner memorize them. I used to be bored with listening to such lessons. I am sure that many students think like me. I do not want to give my students boring lessons. My ideas have changed with STEM education. Classes have become more practical and entertaining.

X26:...It is an effort to intersect what we learn at classes with real life. 
Yildırım, B., \& Selvi, M. (2016). Examination of the effects of STEM education integrated as a part of science, technology, society and environment courses. Journal of Human Sciences, 13(3), 3684-3695. doi: $10.14687 /$ ihs.v13i3.3876

Table 6. Frequency and percentage distribution of the views of the prospective teachers about the level of education STEM education should start

\begin{tabular}{lcc}
\hline Main Themes & $\mathbf{F}$ & $\mathbf{0}$ \\
\hline It should start in nursey schools (ages 2 to 5) & 7 & 9,21 \\
\hline From Kindergarten (age 6) & 30 & 39,47 \\
\hline From Elementary school (ages 7 to 10) & 19 & 25,00 \\
\hline From Secondary School (ages 11 to 14) & 8 & 10,53 \\
\hline From the $1^{\text {st }}$ grade of university (19 and over) & 1 & 1,32 \\
\hline
\end{tabular}

When Table 6 is examined, 9,21\% $(\mathrm{n}=7)$ of the prospective teachers state that STEM education should start as early as nursery school, 39,47\% ( $\mathrm{n}=30)$ marked that it should start from kindergarten, 25\% $(n=19)$ from elementary school, $10,53 \%(n=8)$ from secondary school and $1,32 \%(n=1)$ from university $1^{\text {st }}$ grade. Sample of excerpts from the interviews with the prospective teachers related to this topic are follows:

X4: STEM education should be given starting from primary school. Besides, it argues that engineering should start from primary school ...

X5: ... But the bad point is that we started STEM implementations in the final grade of the university we graduated. In fact, this education should be given from the $1^{\text {st }}$ grade on ...

X9: ...It can be especially starting from pre-school students in every age groups.

X12: ... Thanks to STEM education, students explore their own interests and skills; and people who do their job by loving can achieve professional success. Therefore, STEM education should be applied from primary school level on.

X19:...STEM education should be given from $4^{\text {th }}$ grade on when concrete concepts and abstract concepts are perceived together.

X23:...It should start from the age 6 .

X24:...Starting in the pre-school period will contribute to the child's motor skill development. However, it teaches that problems can be solved in many ways not only from one aspect.

\section{Discuss and result}

The aim of this study is to find out the views of prospective science teachers about STEM education and the effects of STEM education on their attitudes towards Renewable energy resources and on their awareness of environmental problems. To this end, STEM education program developed with the scope of STSE was applied to the fourth grade prospective science teachers at Education Faculty. As a result of the process, interpretations about the effectiveness of the program were made based on the changes it caused on the students.

Within the scope of the study, as a result of analysis of the attitudes of the experimental group in which STEM education within STSE course towards Renewable energy resources and awareness of environmental problems, it was statistically revealed that STEM education had positive effects on students' attitudes towards renewable energy resources (See. Table 1). However, there was not a 
Yıldırım, B., \& Selvi, M. (2016). Examination of the effects of STEM education integrated as a part of science, technology, society and environment courses. Journal of Human Sciences, 13(3), 3684-3695. doi: $10.14687 /$ ihs.v13i3.3876

change in students' awareness of environmental problems (see Table 2). Under the light of these findings, while STEM education had positive effects on the students' attitudes towards renewable energy resources, there were not any changes in students' awareness about of environmental problems.

Prospective teachers argued that STEM education should be given starting from early ages. In a study by Wayne Long (2012), STEM education should be given in primary school and secondary school years. In another study, for engineers and scientists creative thinking problem solving and changing the world are daily activities, children innately have all of these characteristics. Children intrinsically ask questions and want to learn. Therefore, it will be beneficial if STEM education is given at younger ages (Huneycutt, 2013). Weyrick (2010) states that giving STEM education at all levels of education will provide learners with opportunities to acquire cooperative learning, critical thinking, interpersonal communication skills which are called as the $21^{\text {st }}$ century skills and engineering skills.

Keeley (2009) and Goldston (2005) emphasized the importance of giving science education from early ages on. Prospective teachers underscored many positive aspects of STEM education. According to prospective teachers, STEM education is an interdisciplinary approach (Jacobs, 1989; Lederman and Niess, 1997; Wang, Moore, Roehring \& Park, 2011). According to An (2010), STEM education is called as an interdisciplinary approach. Similarly, Morrison (2006) called STEM as an interdisciplinary approach as it established connections between similar disciplines. On the other hand, STEM education allowed students to learn actively, ensured creative thinking (Kim, Gook Ko, Han and Hong, 2014; Kwon, Nam \& Lee, 2012) contributed to the development of problem solving skills (Abdullah, Halim \& Zakaria, 2014; Cotabish, Dailey, Robinson \& Hunghes, 2013; Kim \& Choi, 2012; Kim, Ko, Han, \& Hong, 2014; Kwon, Nam \& Lee, 2012; Park, Nam, Moore \& Roehring, 2011) and allowed learning with group (Ellis \& Fouts, 2001; Morrison, 2006).

Prospective teachers think that STEM education is related to real world problems and life. It has been emphasized by many studies that STEM education is related to real world problems (Baran, Bilici, Mesutoglu \& Ocak, 2016; Rockland et al., 2010; Williams, 2011; Yıldırım, 2016). Besides, STEM education complies with the constructivist approach and allows students to learn by doing and experiencing. In addition, prospective teachers have made different definitions with regard to STEM education. Besides, STEM education help countries meet their qualified manpower and contribute to the countries' economy. There are many studies on the possible benefits of STEM education on countries' economies. According to Roberts (2012), innovation and inventions are effective for countries economy. For individuals to make innovation and inventions, they are to be equipped with $21^{\text {st }}$ century skills. One way to equip students with these skills is to give STEM disciplines and the $21^{\text {st }}$ century skills together. In parallel with the views of Roberts and the prospective teachers in this study, many studies underscore on the importance of STEM education for the scientific, economic and technological development of countries (Brenner, 2009; Hanover Research, 2011; Scott, 2009; National Research Council, 2011).

During STEM education, the prospective teachers have also developed some misconceptions about STEM education as well. One of the chief misconceptions developed was that STEM education is a kind of education given only with Legos and toys. On the other hand, it is also seen that STEM education can only be given in physics lesson and it is suitable only for gifted children. Although the prospective teachers emphasize that STEM education is to be given to gifted children, many studies emphasized that STEM education should be given to all individuals. In a PhD dissertation by Heaverlo (2011), it was maintained that STEM education should be given everyone and especially the interest and attitudes of female students should be developed. 
Yıldırım, B., \& Selvi, M. (2016). Examination of the effects of STEM education integrated as a part of science, technology, society and environment courses. Journal of Human Sciences, 13(3), 3684-3695. doi: $10.14687 /$ ihs.v13i3.3876

In the mentioned study, the researcher found that that females' interest and self-confidence in science and mathematics increased and called it as "Girls' STEM Development". Similarly, Medeiros (2011) stated that STEM education should not be a privilege for certain groups and especially females' attitudes towards science and mathematics should be improved. Contrary to these findings, Meyrick (2011) maintained that STEM education is aimed directly for gifted children. Basically, the researcher explained it by affirming that STEM education will help gifted children to reach results faster. On the other hand, in the same article Meyrick (2011) stated that educators are willing to decrease knowledge and skill differences between students with low ethnic and socio-economic levels and other students. Besides, some negative aspects are also mentioned: STEM education takes time and difficult (Mundfrom, Shelley \& Miller, 1992), some individuals do not participate in group works and it is costly.

\section{Conclusion}

This study examined the effects of STEM education given in science, technology, society and environment courses on prospective teachers' attitudes towards renewable energy sources and environmental problems and on their awareness about environmental problems have been examined. As a result, it has been ascertained that while STEM education has positive contributions to their attitudes, it did not make a difference in their awareness about environmental problems. Besides, in this study the contribution of STEM to the literature has been presented in line with the views of prospective teachers.

It has been determined that prospective teachers do not have adequate knowledge and skills about STEM education and that they have difficulties relating what they have learnt in STEM education to daily life. Thanks to this study, prospective teachers have had chances to relate their knowledge and skills in science, technology, engineering and mathematics with daily life and practically learnt how they can use what they have learnt about STEM disciplines in their daily life.

Prospective teachers who received STEM education think that this education has positive contributions to their individual and professional development. Besides, they suggested that this education should also be given as a course in undergraduate programs. Moreover, prospective teachers emphasized that STEM education should be started as early as nursery school.

For prospective teacher who receive education in disciplines in which science, technology, engineering, and mathematics are the basis, it is important to be knowledgeable and skillful in STEM education. In this respect, this study is important in that it is the first study which revealed that prospective teachers are not adequately equipped with STEM knowledge and skills as they do not receive instruction on STEM at university. This study is considered to provide guidance for further studies on revealing the effects of STEM education on prospective teachers.

In this study, it was determined that prospective teachers had some misconceptions (STEM is a kind of education given via Legos and toys, STEM education can only be given in Physics courses and suitable only for gifted children) about STEM education. It is considered that this study will be a starting point for revealing and removing misconceptions of prospective teachers about STEM education. Therefore, this study will contribute to the literature as it is the first study in which misconceptions about STEM education have been revealed. 
Yildirım, B., \& Selvi, M. (2016). Examination of the effects of STEM education integrated as a part of science, technology, society and environment courses. Journal of Human Sciences, 13(3), 3684-3695. doi: $10.14687 /$ ihs.v13i3.3876

\section{References}

Abdullah, N., Halim, L., \& Zakaria, E., (2014). VStops: A Thinking strategy and visual representation approach in mathematical word problem solving toward enhancing STEM literacy. Eurasia Journal of Mathematics, Science \& Technology Education, 10(3), 165-174.

An, D. (2010). A Meta-analysis of the effectiveness of stem programs in the united states. Unpublished doctoral dissertation, Cleveland State University, Ohio.

Baran, E., Bilici, S.C., Mesutoglu, C. \& Ocak, C. (2016). Moving STEM beyond schools: students' perceptions about an out-ofschool stem education program. International Journal of Education in Mathematics, Science and Technology, 4(1), 9-19.

Brenner, D.C. (2009). Technology education for children council. Technology and Children A journal for Elementary School Technology Education, 14(1), 14.

Cotabish, A., Dailey, D. Robinson, A., \& Hunghes, G., (2013). The Effects of a STEM intervention on elementary students' science knowledge and skills. School Science and Mathematics, 113(5), 215-226.

Dugger, W. E. (2010). Evolution of STEM in the united states. Paper presented at the 6th Biennial International Conference on Technology Education Research, Gold Coast, Queensland, Australia.

Ellis, A., \& Fouts, J. (2001). Interdisciplinary curriculum: the research base: the decision to approach music curriculum from an interdisciplinary perspective should include a consideration of all the possible benefits and drawbacks. Music Educators Journal, 87(22), 22-26, 68.

Goldston, D. (2005). Elementary science: left behind?. Journal of Science Teacher Education, 16, 185187.

Gonzalez, H. B., \& Kuenzi, J. J. (2012). Science, technology, engineering and mathematics (STEM) education: A Primer. Congressional Research Service. Retrieved July 25, 2015 from https://www.fas.org/sgp/crs/misc/R42642.pdf .

Güneş, T. Alat, K. \& Can Gözüm, A.İ. (2013). Fen Öğretmeni Adaylanına Yönelik Yenilenebilir Enerji Kaynakları Tutum Ölçeği: Geçerlilik ve Güvenirlik Çalışması. Eğitim Bilimleri Arastirma Dergisi, 3(2), 269-289.

Güven, E. \& Aydoğdu, M. (2012). Çevre Sorunlarına Yönelik Farkındalık Ölçeğinin Geliştirilmesi ve Öğretmen Adaylarının Farkındalık Düzeylerinin Belirlenmesi. Öğretmen Eğitimi ve Eğitimcileri Dergisi. 2, 185-202.

Hanover Research. (2011). K-12 STEM Education Overview, HR, 11.

Heaverlo, C. (2011). STEM Development: A Study of 6th-12th Grade Girls' Interest and Confidence in Mathematics and Science. Doctoral dissertation. Iowa State University, Lowa.

Huneycutt, T. (2013). Starting STEM early: the need for vertical alignment. Retrieved October 16, 2015 from http://www.nms.org/Blog/TabId/58/PostId/212/starting-stem-early-theneed-for-vertical-alignment.aspx.

Jacobs, H.H. (1989). Interdisciplinary curriculum: design and implementation. Alexandria, VA: Association for Supervision and Curriculum Development.

Keeley, P. (2009). Form and substance of in-service teacher education. Madison, WI: National Institute for Science Education, University of Wisconsin-Madison.

Kim, D.H., Gook Ko, D., Han, M.J., \& Hong, S.H. (2014). The Effects of science lessons applying STEAM education program on the creativity and interest levels of elementary students. Journal of the Korean Association for Science Education, 34(1), 43-54.

Kim, D.H., Ko, D.G., Han, M.J., \& Hong, S.H. (2014). The Effects of science lessons applying STEAM education program on the creativity and interest levels of elementary students. Journal of the Korean Association for Science Education, 34(1), 43-54. 
Yildirım, B., \& Selvi, M. (2016). Examination of the effects of STEM education integrated as a part of science, technology, society and environment courses. Journal of Human Sciences, 13(3), 3684-3695. doi:10.14687/jhs.v13i3.3876

Kim, G.S., \& Choi, S.Y., (2012). The effect of Creative problem solving ability and scientific attitude through the science based STEAM program in the elementary gifted students. Elementary Science Education, 31(2), 216-226.

Koonce, D.A., Zhou, J., Anderson, C.D., Hening, D.A., \& Conley, V.M. (2011). What is STEM? Paper presented at the $8^{\mathrm{TH}}$ ASEE Annual Conference \& Exposition, Vancouver, Canada.

Kwon, S.B., Nam, D.S., \& Lee, T.W. (2012). The Effects of STEAM-based integrated subject study on elementary school students' creative personality. The Korea Society of Computer and Information, 17(2), 79-86.

Lederman, N.G. \& Niess, M.L., (1997). Integrated, interdisciplinary, or thematic instruction? is this a question or is it questionable semantics?. School Science and Mathematics, 97(2), 57-58.

Medeiros, D.J. (2011). The Influence of female social models in corporate STEM initiatives on girls' math and science attitudes. Doctor dissertation, The University of Pennsylvania, Philadelphia.

Meyrick, K. M. (2011). How STEM education improves student learning. Meridian K-12 School Computer Technologies Journal. 14(1).

Morrison, J. (2006). TIES STEM education monograph series, attributes of STEM education. Baltimore, MD: TIES.

Mundfrom, D.J., Shelley, M.C. \& Miller, W.G. (1992). Perceptions of Course Difficulty. Presented at the Winter Conference of The American Statistical Association, New York.

National Research Council (2011). Successful K-12 STEM education. Washington, DC: National Academy.

Roberts, A. (2012). A Justification for STEM education. technology and engineering teachere. Retrieved April 15, 2015, from http://www.iteaconnect.org/mbrsonly/Library/TTT'T/T'TTe/0412roberts.pdf

Rockland, R., Bloom, D. S., Carpinelli, J., Burr-Alexander, L., Hirsch, L. S. \& Kimmel, H. (2010). Advancing the "E" in K-12 STEM education. Journal of Technology Studies, 36(1), 53-64.

Park, M., Nam, Y., Moore, T.J. \& Roehring, G. (2011). The Impact of integrating engineering into science learning on student's conceptual understandings of the concept of heat transfer. Journal of the Korean Society of Earth Science Education, 4(2), 89-101.

Scott, M.C. (2009). Technology education for children council, technology and children. A journal for Elementary School Technology Education, 14(1), 3.

Wang, H.H., Moore, Tamara J. Roehrig, Gillian H. \& Park, M. S. (2011). STEM integration: teacher perceptions and practice. Journal of Pre-College Engineering Education Research 1(2).

Wayne Long, A. (2012). Heightening Interest in STEM Through a Mentoring Project Between Undergraduate and Middle School Students. Master's Thesis. Youngstown State University, Ohio.

White, D.W. (2014). What Is STEM education and why is it important?. Florida Association of Teacher Educators Journal, 1(14), 1-9.

Williams, J. (2011). STEM education: proceed with caution. Design and Technology Education,16(1), 2635.

Yildirım, B. (2016). An Examination of the effects of science, technology, engineering, mathematics (STEM) applications and mastery learning integrated into the 7 th grade science course. Unpublished Doctoral dissertation. Gazi University, Ankara.

Yildırım, B., \& Altun, Y. (2015). Investigating the effect of STEM education and engineering applications on science laboratory lectures. El-Cezerî Journal of Science and Engineering, 2(2); 2840.

Yıldırım, B. \& Selvi, M. (2015). Adaptation of STEM attitude scale to Turkish. Turkish Studies International Periodical for the Languages, Literature and History of Turkish or Turkic, 10(3), 11071120. 